\title{
THE CHEMICAL COMPOSITION AND CAPACITY FOR PROTEIN SYNTHESIS OF THE LIVER OF CATTLE SUFFERING FROM CLINICAL JOHNE'S DISEASE
}

\author{
D. S. P. Patterson, W. M. Allen, Sylvia Berrett \\ AND D. SWEASEY \\ Central Veterinary Laboratory, Weybridge
}

IN previous papers on the changes in the chemical composition of skeletal muscle in clinical Johne's disease it was suggested that in wasting muscles protein synthesis was depressed through deficient formation of adenosine triphosphate (ATP) via the creatine phosphokinase (CPK) reaction (Patterson, Allen and Slater, 1966; Patterson et al., 1968b). This raised questions as to whether protein synthesis was affected generally in the tissues of cows suffering from clinical Johne's disease, and whether the liver in particular was affected, as shown by altered chemical composition.

The present results show that in advanced clinical cases of Johne's disease, the composition of the liver, unlike that of muscle, appears unaffected except for early fibrosis indicated by a substantial increase in " collagen" content. Other changes, such as a decrease in ATP content, were found to be small and there was no evidence for depressed protein synthesis.

\section{MATERIALS AND METHODS}

Animals. Comparisons were made between five clinically affected cows that had been brought to the laboratory for investigation between 7 and $11 \mathrm{mth}$ beforehand and six apparently healthy cows kept on the laboratory farm. All the clinical cases of Johne's disease were first diagnosed by positive faecal smears and complement fixation test and an unequivocal diagnosis was made at necropsy.

Liver biopsy procedure. To complete most of the biochemical analyses, large samples of liver $(20-30 \mathrm{~g})$ were required and a laparotomy technique (Hibbitt and Baird, 1967) was used for this purpose. This procedure is probably less liable to errors from contamination with blood (Patterson and Allen, 1968) than the cannula method of Loosmore and Allcroft (1951) which was used for obtaining small liver samples for the estimation of the hydroxyproline content.

The specimen was blotted free of contaminating blood and stored on ice during the short return journey to the laboratory. For the determination of ATP, however, the metabolic activity of a separate portion of the liver was quenched by immediately dropping it into liquid nitrogen.

Homogenates. With the exception of the samples reserved for ATP estimations, all the analyses were performed on homogenates of liver tissue in 9 volumes of ice-cold water. A "Silverson" Stainless steel top-drive mechanical homogeniser run at 6000 r.p.m. for $20-30 \mathrm{~s}$ at $0^{\circ} \mathrm{C}$ was used. Convenient volumes of the homogenate were allocated for the various assays which were then commenced with minimum delay.

Chemical analyses. Estimates of dry matter, water content, total nitrogen, protein nitrogen, and non-protein nitrogen, nitrogenous extractives, hydroxyproline, nucleic acids

Received 12 Jan. 1968; accepted 25 Mar. 1968.

J. MED. MICROBIOL. - VOL. 1 (1968) 
(RNA and DNA), acid soluble ribonucleotides and ATP were made by methods described in the preceding paper (Patterson et al., 1968b). Total lipid content was determined by the method of Sperry (1955).

Liver enzyme assays. Lactate dehydrogenase (LDH) activity was assayed in a 100-fold dilution of the original liver homogenate by the ultraviolet spectrophotometric procedure of Bergmeyer, Bernt and Hess (1963). For glucose-6-phosphatase (G-6-Pase) the procedure of Ashmore and Weber (1959) was employed and for hexose monophosphate dehydrogenase (HMPD) (glucose-6-phosphate plus 6-phosphogluconate dehydrogenases) the method of Glock and McLean (1953); both assays were performed on the undiluted homogenate.

In-vitro assay of protein synthesis. An estimate of the hepatic protein synthetic activity was obtained by measuring the rate of incorporation of [U-14C] leucine into the protein of liver slices. The tissue slices were prepared with the tissue chopper described by Mcllwain and Buddle (1953) and the assay procedure was a modification of that used by Clifford and Rees (1967). Liver slices of approximately $100 \mathrm{mg}$ were incubated in $3 \mathrm{ml} \mathrm{Krebs-}$ Ringer phosphate solution containing labelled leucine in a shaker-water-bath at $37^{\circ} \mathrm{C}$ in an atmosphere of oxygen. After 2 hours' incubation $2 \mathrm{ml}$ of 20 per cent. trichloroacetic

TABLE I

Main constituents of liver from healthy cows and from cows with clinical Johne's disease

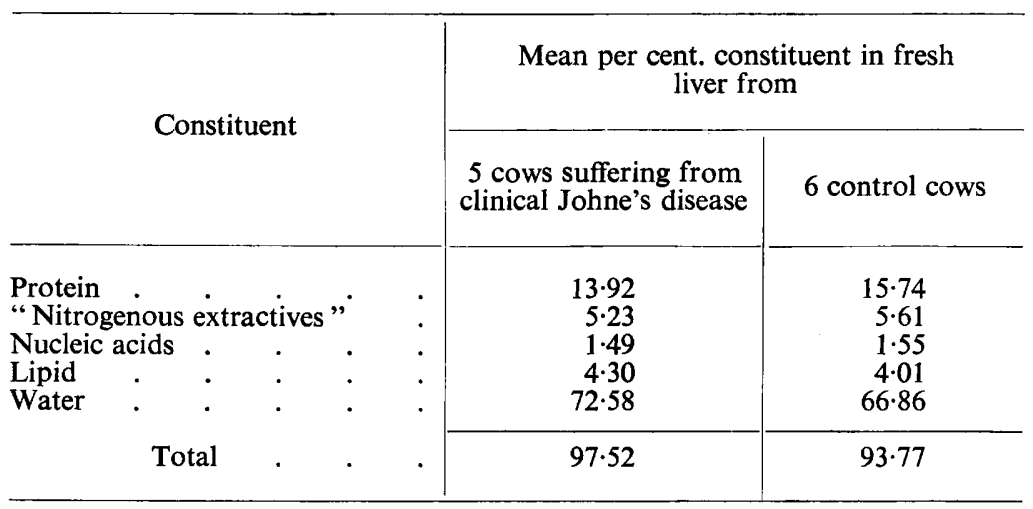

acid (TCA) was added with mixing. The precipitated protein was subsequently washed three times with 8 per cent. TCA containing 0.1 per cent. L-leucine, then once with ethanol and twice with ether. After it had been dried in air at room temperature, the fat-free powder was dissolved in $3 \mathrm{ml} \mathrm{N}-\mathrm{NaOH}$ by heating to $70^{\circ} \mathrm{C}$ for $60 \mathrm{~min}$; ; a convenient volume was then added to $10 \mathrm{ml}$ of a solution prepared from $4 \mathrm{~g}$ BBOT (2,5-bis-[5'-tert-butyl-benzoxazolyl ( $\left.\left.2^{\prime}\right)\right]$-thiophene, CIBA), $80 \mathrm{~g}$ naphthalene, $600 \mathrm{ml}$ toluene and $400 \mathrm{ml}$ methylcellosolve. After a period of equilibration, the radioactivity was measured with a type- 6012 scintillation counter (Isotope Developments, Ltd). Rates of protein synthesis were measured as nCilabelled leucine incorporated per $\mathrm{g}$ fat-free dry matter per $\mathrm{hr}$ at $37^{\circ} \mathrm{C}$.

\section{RESULTS}

\section{Comparison of the chemical composition of livers from normal cows and clinical cases of Johne's disease}

Five major constituents of liver (protein, " nitrogenous extractives", nucleic acids, lipids and water) accounted for 94-98 per cent. of its fresh weight (table I). Concentrations of the individual constituents were not significantly different for the two groups of animals. 
The partition of nitrogen was also similar. Protein nitrogen represented about 73 per cent. of the total nitrogen in the liver of diseased cows, compared with about 74 per cent. in healthy controls. However, there was a highly significant increase in the "collagen" content of the liver in the clinically affected animals (table II). "Collagen " was calculated from the hydroxyproline content, on the assumption that collagen contains about 12 per cent.

TABLE II

Partition of nitrogen and " collagen" content of liver

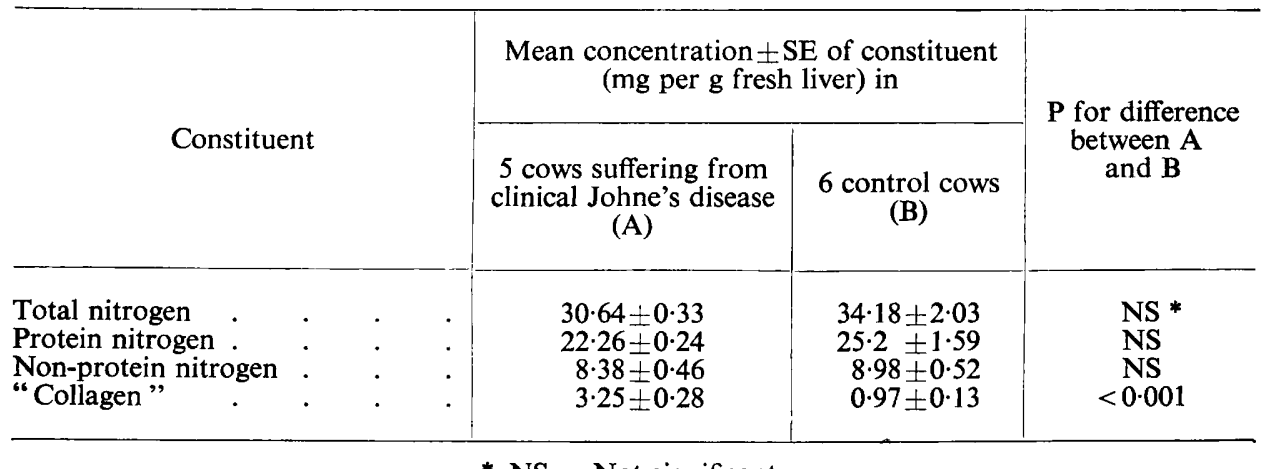

* NS $=$ Not significant.

TABLE III

Nucleic acids and nucleotides in livers from healthy cows and from clinical cases of Johne's disease

\begin{tabular}{|c|c|c|c|c|}
\hline \multirow{2}{*}{\multicolumn{2}{|c|}{ Constituent }} & \multicolumn{2}{|c|}{$\begin{array}{c}\text { Mean concentration } \neq \text { SE of constituent } \\
\text { per } g \text { fresh liver from }\end{array}$} & \multirow{2}{*}{$\begin{array}{l}\text { Significance of } \\
\text { difference } \\
\text { between } \\
\mathrm{A} \text { and } \mathrm{B}\end{array}$} \\
\hline & & $\begin{array}{c}5 \text { cows suffering from } \\
\text { clinical Johne's disease } \\
\text { (A) }\end{array}$ & $\begin{array}{l}6 \text { control cows } \\
\text { (B) }\end{array}$ & \\
\hline $\begin{array}{l}\text { RNA (mg) . } \\
\text { DNA (mg) . } \\
\text { Acid-soluble ribonucleotides } \\
\text { (arbitrary OD units) }\end{array}$ & $\dot{\cdot}$ & $\begin{array}{r}8 \cdot 38 \pm 0 \cdot 44 \\
6 \cdot 48 \pm 0 \cdot 46 \\
21 \cdot 62 \pm 1 \cdot 10\end{array}$ & $\begin{array}{r}8.90 \pm 0.90 \\
6.57 \pm 0.47 \\
24.56 \pm 1.83\end{array}$ & $\begin{array}{l}\text { NS } \\
\text { NS } \\
\text { NS }\end{array}$ \\
\hline ATP $(\mu$ moles $)$ & - & $1 \cdot 59 \pm 0 \cdot 067$ & $1 \cdot 91 \pm 0 \cdot 22$ & NS \\
\hline
\end{tabular}

hydroxyproline. This amino acid is a characteristic constituent of collagenous connective tissue and its increase indicates a small, but significant, degree of cirrhosis in Johne's disease.

There was also a small but significant $(\mathrm{P}<0.05)$ increase in total liver lipids from $12 \cdot 1$ to $15 \cdot 7$ per cent. dry weight of liver, the mean values indicating that an additional 3.6 per cent. of the dry matter was accounted for by lipids in the livers from clinical cases of Johne's disease.

Concentrations of liver nucleic acids (both RNA and DNA) were not significantly different in the two groups of animals, neither was there a significant 
alteration in the RNA/DNA ratio $(1.30 \pm 0.034$ for sick cows; $1.36 \pm 0.099$ for controls). Mean values for the concentrations of acid-soluble ribonucleotides and for ATP were some 12 and 17 per cent. lower respectively in the liver in Johne's disease than in the healthy controls, but these differences were not statistically significant (table III).

\section{Protein synthesis}

The rate of hepatic protein synthesis was not depressed in Johne's disease, a fact indicated by the unchanged RNA/DNA ratio. Furthermore, there was no decrease in the liver ATP concentration to suggest an impairment due to a shortage of this cofactor. A direct assessment of the rate of protein synthesis was however also made in liver samples obtained from 2 severely affected animals and in samples from 3 healthy control cows. Measurements of the rate of incorporation of $\left[\mathrm{U}-{ }^{14} \mathrm{C}\right]$ leucine into the protein of liver slices in incubation experiments suggested that, far from there being a diminution in the rate of protein synthesis, there was an almost two-fold increase. The levels of activity of three unrelated enzymes were also assayed in homogenates of the liver tissues at the same time. In each case there was a considerable decrease compared with the controls (table IV). This apparent anomaly suggests that while over-all rates of protein synthesis are increased, specific proteins like the three enzymes assayed (since they represent only a small fraction of the total liver proteins) may still be present at abnormally low concentrations in Johne's disease.

TABLE IV

Liver enzymes and protein synthetic activity

\begin{tabular}{|c|c|c|c|c|}
\hline \multirow[b]{2}{*}{ Livers from } & \multicolumn{3}{|c|}{ Enzyme activity in liver } & \multirow{2}{*}{\begin{tabular}{|c|}
$\begin{array}{c}\text { Protein synthesis } \\
\text { in liver }\end{array}$ \\
[U-14C] leucine \\
uptake (nCi of \\
$14 \mathrm{C}$ per g fat-free \\
dried material per \\
hr at $37^{\circ} \mathrm{C}$ )
\end{tabular}} \\
\hline & $\begin{array}{c}\text { Lactate } \\
\text { dehydrogenase } \\
(\mu \text { moles per g per } \\
\left.\text { min. at } 25^{\circ} \mathrm{C}\right)\end{array}$ & $\begin{array}{c}\text { glucose-6- } \\
\text { phosphatase } \\
\text { ( } \mu \text { atoms P per g } \\
\left.\text { per min. at } 37^{\circ} \mathrm{C}\right)\end{array}$ & $\begin{array}{c}\text { hexose mono- } \\
\text { phosphate } \\
\text { dehydrogenase } \\
(\mu \text { moles per g per } \\
\left.\text { min. at } 25^{\circ} \mathrm{C}\right)\end{array}$ & \\
\hline $\begin{array}{l}2 \text { cows with clinical } \\
\text { Johne's disease }\end{array}$ & $\begin{array}{l}51 \cdot 5 \\
61 \cdot 8\end{array}$ & $\begin{array}{l}13 \cdot 6 \\
17 \cdot 1\end{array}$ & $\begin{array}{l}1 \cdot 22 \\
1.03\end{array}$ & $\begin{array}{l}27 \cdot 1 \\
28 \cdot 5\end{array}$ \\
\hline 3 control cows & $\begin{array}{r}131 \cdot 3 \\
244 \cdot 5 \\
77 \cdot 3\end{array}$ & $\begin{array}{l}29 \cdot 0 \\
27 \cdot 4 \\
23 \cdot 5\end{array}$ & $\begin{array}{l}1.89 \\
2.08 \\
1.60\end{array}$ & $\begin{array}{l}19 \cdot 8 \\
11.9 \\
12.8\end{array}$ \\
\hline
\end{tabular}

\section{Liver size and function}

In the wasted, clinically sick animals, the liver was relatively larger than in normal healthy cows $(2.5$ per cent. of body weight compared with 1.56 per cent. for the controls). Provided there is normal liver function (and there is no evidence to the contrary) this is more than an adequate amount of tissue for 
the cows' needs. There was probably no actual increase in organ size due to tissue proliferation since the DNA content (a measure of nuclear material) and the calculated mean hepatic cell size for the two groups (table V) were not significantly different.

TABLE V

Relative liver weight and mean liver cell size

\begin{tabular}{|c|c|c|c|}
\hline \multirow{2}{*}{ Estimate } & \multicolumn{2}{|c|}{$\begin{array}{l}\text { Mean value of estimate } \pm S E \\
\text { in liver from }\end{array}$} & \multirow{2}{*}{$\begin{array}{l}\mathbf{P} \text { for difference } \\
\text { between } \mathbf{A} \\
\text { and } \mathbf{B}\end{array}$} \\
\hline & $\begin{array}{l}5 \text { cows suffering from } \\
\text { clinical Johne's disease } \\
\text { (A) }\end{array}$ & $\begin{array}{l}\text { control cows } \\
\text { (B) }\end{array}$ & \\
\hline $\begin{array}{l}\text { Liver weight * (as per cent. body } \\
\text { weight) }\end{array}$ & $2 \cdot 50 \pm 0.086$ & $1 \cdot 56 \pm 0 \cdot 12(7) \dagger$ & $<0.001$ \\
\hline $\begin{array}{l}\text { Liver cell size (as mg fresh weight } \\
\text { liver per mg DNA) }\end{array}$ & $15 \cdot 72 \pm 1 \cdot 03$ & $15 \cdot 53 \pm 1 \cdot 13(6)$ & NS \\
\hline
\end{tabular}

* Obtained at necropsy.

$\dagger$ Figures in brackets give number of cows.

\section{Discussion}

Earlier unpublished observations had indicated substantial differences in the composition of liver taken at biopsy from clinical cases of Johne's disease compared with healthy cows. These differences occurred mainly in the protein and nucleic acid contents. However, it was subsequently found that the findings were due to the use of two different biopsy techniques (cannula or laparotomy). The differences probably resulted from the greater contamination of cannula biopsies with blood (Patterson and Allen, 1968) and disappeared when the data were obtained by a single biopsy procedure. With the sole exception of the hydroxyproline determinations, which were made on cannula specimens, all the analytical data presented here were obtained on laparotomy samples.

In broad terms, the chemical composition of liver in Johne's disease is apparently normal; there is no decrease in protein content expressed either on a fresh weight basis or as the ratio of protein N/DNA. Another difference from the results for wasted muscle (Patterson et al., 1968b) was the absence of a reduced ATP content that could have affected the rate of liver protein synthesis in Johne's disease. Finally, the mean hepatic cell size and DNA concentration were similar for the two groups of animals although the liver was relatively larger in sick cows. Thus, there was neither evidence of cell shrinkage (as in wasting muscle) nor of cellular proliferation.

Two abnormalities are worthy of comment: the slight increase in hepatic fat and the apparently large increase in connective-tissue content. Both of these changes may be seen in the liver during starvation and in protein malnutrition (Nicholls, 1961; Viteri et al., 1964). The small increase in fat may be 
related to the enhanced rate of depot-fat mobilisation seen in clinical Johne's disease (Patterson et al., 1968a). A dependence of the accumulation of liver fat on fat mobilisation has, in fact, been noted in starving sheep (Patterson, 1966). However, the small increment in hepatic fat in Johne's disease, unlike that in starving sheep or undernourished human beings, would not be visible either to the naked eye or histologically. The increased hydroxyproline content and presumed increase in liver connective tissue are suggestive of an early fibrosis. This observation is not invalidated by the fact that cannula biopsy specimens were used for the relevant analyses because, although excess blood was always present, the increase to approximately three times the normal hydroxyproline content in liver from Johne's cases could not be accounted for merely by a variation in blood contamination.

There has been no indication of diminished protein synthesis in the liver of clinical cases of Johne's disease. The opposite is apparently true and perhaps this is associated with an increased turnover of protein. Nevertheless, there may be decreases in the amount of specific proteins synthesised. Thus, it was possible to demonstrate decreases in the liver contents of three enzymes. This may be related to a decreased metabolic requirement of the wasted animal, in which all that the relatively large liver is doing is to maintain a total amount of metabolic equipment (enzymes) adequate for the reduced body weight and, in doing so, to produce a reduced concentration of enzymes in terms of activity per $\mathbf{g}$ fresh weight. Alternatively, these decreased enzyme activities may be an adaptation to a diminished through-put of substrates in the clinical subject, which is in effect a semi-starved animal. Finally, it is also possible that a hormonal control of metabolism may be exerted, that ultimately produces these observed effects.

In the natural infection with Mycobacterium johnei in cattle the lesions are primarily in the intestines, but eventually the organisms are disseminated, probably via the lymphatics, so that a stage is reached when organisms may be recovered from the spleen and liver. However, macroscopic or microscopic liver lesions are rarely seen. To this extent, the relatively unchanged composition of the liver was probably to be expected. In other species, like the mouse, and in experimental situations (e.g., after intravenous infection), where the liver is a primary focus for the infecting organisms, the chemical composition of the liver may possibly undergo significant alteration.

\section{SUMMARY}

Liver tissue was obtained from 5 cases of clinical Johne's disease by biopsy and analysed for total nitrogen, protein nitrogen, "collagen ", lipid, nucleic acids, acid-soluble ribonucleotides and ATP. Comparisons were made with liver tissue from healthy cows. The only significant changes in chemical composition were a small rise in liver lipid content and a marked increase in tissue hydroxyproline, indicating increased connective tissue and suggesting early fibrosis.

The in-vitro rate of protein synthesis was assayed in 2 clinical cases and 3 
controls by means of the rate of incorporation of $\left[\mathrm{U}-1{ }^{14} \mathrm{C}\right]$ leucine into the proteins of liver slices. A higher than normal rate of synthesis was observed in the liver tissue from the cows with clinical Johne's disease but, at the same time, tissue concentrations of three enzymes (glucose-6-phosphatase, hexose monophosphate dehydrogenase and lactate dehydrogenase) were lowered.

\section{REFERENCES}

AshmoRe, J., AND Weber, G. . . . . 1959. Vitams Horm., 17, 91.

Bergmeyer, H-U., BerNT, E., AND 1963. In Methods of enzymatic analysis, ed. Hess, B.

Clifford, Janet I., ANd Rees, K. R. 1967. Biochem. J., 102, 65.

Glock, Gertrude E., ANd Mclean, 1953. Ibid., 55, 400.

Patricia

HibBitt, K. G., ANd Baird, G. D. . . 1967. Vet. Rec., 81, 511.

LOOSMORE, R. M., AND Allcroft, Ruth 1951. Ibid., 63, 414.

Mcllwain, H., AND Buddle, H. L. . 1953. Biochem. J., 53, 412.

NichOLLS, L.

1961. In Tropical nutrition and dietetics, 4 thed., by H. M. Sinclair and D. B. Jelliffe, London, p. 156.

PAtterson, D. S. P. . . . . . . . 1966. Res. Vet. Sci., 7, 484.

Patterson, D. S. P., and Allen, W. M. 1968. Vet. Rec., 82, 35.

Patterson, D. S. P., Allen, W. M., 1968a. Res. Vet. Sci., 9, 117.

Berrett, Sylvia, IVINS, L. N., AND

SWEASEY, D.

Patterson, D. S. P., Allen, W. M., 1968b. J. Med. Microbiol., 1, 127.

Berrett, Sylvia, Sweasey, D., and

Slater, T. F.

Patterson, D. S. P., Allen, W. M., AND 1966. Biochem. J., 101, 38P.

Slater, T. F.

SPERRY, W. M. .

1955. Meth. Biochem. Analysis, 2, 83.

Viteri, F., Béhar, M., Arroyave, G., 1964. In Mammalian protein metabolism, ed. AND SCRIMSHAW, N. S. by $\mathbf{H}$. N. Munro and J. B. Allison, London, vol. 2, p. 523. 